\title{
Proposal for OEE (Overall Equipment Effectiveness) Indicator Deployment in a Beverage Plant
}

\author{
Fabiana Pereira Castro \\ Fernando Oliveira de Araujo \\ Federal Center for Technological Education of Rio de Janeiro (CEFET/RJ), \\ Rio de Janeiro, RJ, Brazil
}

\begin{abstract}
The tough competitiveness seen in the beverage industry, especially in emerging segments like isotonic drinks and iced teas, requires companies to seek competitive advantages to stay or increase their participation in the consumer market. In this sense, reducing wastes and assuring compliance in production process are identified as key variables in this industry. This work presents the application of the OEE (Overall Equipment Effectiveness) indicator in the production line of a company which fills beverage in PET bottles, in order to assess the plant operational performance. In this direction, primary data were collected and the line downtimes were stratified, and the indicators used by the plant were confronted with the dimensions that make up the OEE indicator (Availability, Performance and Quality) in order to evaluate the possible behaviors and correlations. As a result, it was noted that the longest downtimes were caused by problems with the inkjet printer and the filler, and there was a strong correlation between the indices of the OEE and the existing indicators in the plant despite the bias $(\varepsilon)$.
\end{abstract}

Keywords: Overall Equipment Effectiveness - OEE, Beverage industry, Lean thinking, Operational performance indicators.

\section{Introduction}

Some of the great challenges faced in the industrial environment regard the correct, efficient use of the resources available both operational and manpower for the production. In continuous production systems high productivity through appropriate distribution of these resources and adequate operational procedures becomes a priority. However productivity in such production systems depends directly on the efficiency of their critical operations or "bottlenecks" (Moellmann et al., 2006; Moraes and Santoro, 2006).

According to the research by Gomes (2002), training staff, improving machines, devices and accessories - making them easier, safe and easy to maintain - provide the necessary conditions for the consolidation of a new way of thinking and acting, fomenting the culture of organization. Among the authors queried by the author there is a consensus about the need for seeking a new way of work which maximizes the efficiency of all the production system through the plant floor's active and integrated participation, by use of the philosophy of oriented management for the equipment, in order to assure permanence in market. 
According to Fuentes (2006) and Masud et al. (2007), the concept of Total Productive Maintenance (TPM) can be defined as a form of management designed to enhance the total efficiency of the equipment by establishing a detailed productionmaintenance system which encompasses the equipment life cycle. TPM management pattern aims at eliminating wastes and the evolution of the business structure, based on eight pillars:

- Planned maintenance;

- Education and Training;

- Initial Control;

- Focused Improvement;

- Autonomous Maintenance;

- Safety, Health and Environment;

- Office/ Administrative TPM;

- Quality Maintenance.

TPM encompasses aspects such as: design, use and maintenance, and professes all the staff participation, from high management to the "plant floor", in order to promote productive maintenance through motivating administrative activities or small voluntary groups (Fuentes, 2006).

\section{Description of the Problem Situation}

This study analyzes the case of a company which bottles isotonic drinks and iced teas. The company, despite its well known performance in the Brazilian beverage industry - evidenced by its recent acquisition by a multinational giant of relevance in the world beverage market - still does not have consolidated practices of monitoring of its production process, primarily regarding the assessment of its machinery operational performance.

The incorporation of the mentioned company by the multinational group, provided with strict international patterns of productive efficiency, makes it mandatory that practices of analysis and stratification of the production line downtimes became incorporated with the purpose of enhancing the operational efficiency of the use of manufacturing technologies. In particular the present work assesses the operational performance of a PET bottle filler in a beverage plant through deploying an indicator of overall equipment effectiveness (OEE).

\section{Objectives}

In general terms, this study aims to define parameters, measure the OEE indicator and, from the results, identify the possible causes of the wastes and equipment failures, proposing process improvements in a beverage filling system that uses PET bottles.

Specifically, this study aims:

- To confront the data found with the specialized literature available; 
- To apply appropriate methodology for analysis of failures and production line downtimes, in order to optimize the efficiency of resources used in the beverage production;

- To reduce the rework of PET bottle filler, optimizing the efficiency of the resources used in the beverage production;

- To use the OEE indicator correlating it to other indicators as a support to decisions of the industrial management.

\section{Presumptions of the Study}

- The performance indicators currently used are not satisfactory to monitor the operational efficiency;

- To verify if the management does not act proactively in eliminating wastes in the production process;

- The rework in filling drinks in PET bottles causes significant impact in the plant's productivity.

\section{The Study Delimitation}

This work presents primary data derived from case study in a beverage company located in the city of Rio de Janeiro. The company concerned does not use the concepts of Total Productive Maintenance (TPM) as a strategic factor or establishes a method of cause analysis aiming at minimizing productivity wastes, in spite of planning actions of Corrective and Preventive Maintenance for production and maintenance management.

The investigation is limited to monitoring the OEE indicator in a machine for filling beverage in PET bottles of $1500 \mathrm{~mL}$, operating in a continuous regime of approximately 4,800 units per hour.

\section{Methodology}

\section{The Research Classification}

The work is classified as a case study of quantitative and exploratory nature. It is proposed to be a research to better know the process variables, creating greater familiarity with the problem and serving as a basis for outlining a more specific and deeper investigation in the future (Rodrigues et al., 2005; Lacerda et al., 2007).

\section{Data Collection Techniques}

The case study was based on observations for planning and structuring the data collection, using data collection techniques such as: revision of the technical scientific literature, research of data forms of production and materials of the best practices available by the company, and interviews with the operational and tactic level of the studied company.

\section{Method Limitations}

The method used in this study for measuring the Overall Equipment Effectiveness (OEE) indicator has the following limitations: 
- The metrics does not encompass the production accomplished in extra hours, so it was subtracted from the calculation basis;

- The indication of downtimes in the line presents bias $(\varepsilon)$ for being manual and sometimes suppressed or partially exposed, making the use in these cases unviable;

- Estimate of the real amount of used packages (inputs) due to the lack of real consume data;

- Inconsistent database of the ERP system used by the plant;

- Manual count of discarded and reused packages causing bias $(\varepsilon)$ onto the calculation of the quality indicator.

\section{Literature Review}

\section{Lean Thinking}

In the 1950s the Lean Thinking, initially conceived by Toyota's Production System, in Japan, aimed at producing more efficient cars in a post war country. In the 1990s, this thinking line was presented by James Womack and Daniel Jones for mass production companies to also become lean, adding new elements to initial conceptions of Taiichi Ohno, the mastermind of the Toyota Production System. The pattern expanded to companies of repetitive manufacturing of high and low volume and service operation systems (Giannini, 2007).

The lean thinking has as main proposal the generation of value for the client by eliminating wastes, making the organization more competitive in the market. The Lean philosophy identifies 7 major sources of wastes, suggesting techniques for eliminating or optimizing activities that do not add value to the client (Fernandes and Ramos, 2006).

According to Kmita et al. (2003), professed by the Toyota's Production System, the 7 sources of wastes are:

1. Wastes due to overproduction;

2. Wastes due to transportation;

3. Wastes due to over processing;

4. Wastes due to manufacturing defective products;

5. Wastes due to motion;

6. Wastes due to waiting;

7. Wastes due to inventory.

This work will be restricted to describing the two wastes deemed more relevant to the study: the waste due to manufacturing defective products and the waste due to the processing itself.

In his bibliographical survey, Falcão (2001, p. 72) describes the wastes due to manufacturing defective products as 
[...] they consist in parts, subcomponents, and accomplished products that are not in accordance with quality specifications. This kind of waste is more usual and visible, since it is evidenced exactly in the production object, requiring rework or eventual rejects.

Whereas the waste due to the processing itself may be defined as a performance of unnecessary process activities for the product to achieve the characteristics desired by the client, so that it may cause wastes (Giannini, 2007).

To the 7 major sources of wastes, the Japanese Institute of Plants Maintenance (JIPM) adds other eleven, summing 17 sources of wastes (Souza, 2004):

a) Wastes due to planned maintenance;

b) Wastes due to short downtimes;

c) Wastes due to administrative failures;

d) Wastes due to operating failures;

e) Wastes due to disorganization;

f) Wastes due to logistics;

g) Wastes due to the use of the manpower;

h) Wastes due to waiting;

i) Wastes due to energy;

j) Wastes to the use of matrixes and templates;

k) Wastes due to low yield.

Fernandes and Ramos (2006) mention tools and concepts to make production lean, among which is TPM as a way of assuring the process stability and Kaizen for defect reduction and improvement of production processes.

\section{Overall Equipment Effectiveness (OEE)}

The analysis of the production systems efficiency is a relevant topic to industrial companies. By calculating and monitoring resource productive efficiency it is possible to know their actual efficiencies, having as an objective to elaborate action plans and solution for the main reasons of production inefficiency. Since the information for correct calculation of resource efficiency is not always available in the companies' corporate systems, it is necessary to collect and analyze data from the productive resources (Passos et al., 2004). The adoption of a correct measurement system and the management of key parameters are able to contribute for the increase of productivity of both multifunctional areas and the plant (Hansen, 2006).

One of the most important tools in the TPM philosophy is the Overall Equipment Effectiveness (OEE). The OEE indicator is a result of the multiplication of three parameters which have a relevant role in the TPM philosophy (Fuentes, 2006; Muchiri and Pintelon, 2008).

Bariani and Del'Arco Júnior (2006) and Maran et al. (2012) define the parameters as: 
- Availability: It is the amount of time in which some equipment has been available to work in comparison with the amount of time in which it was programmed to work;

- Performance It is how much the equipment works near the ideal time cycle to produce a piece;

- Quality: It is the total number of good pieces produced in comparison with the total number of produced pieces.

Figure 1 and Table 1 show each index and the main failures that may interfere with its performance:

The Overall Equipment Efficiency may be represented by:

Overall Equipment Efficiency $(\mathrm{OEE})=$ Availability $\times$ Performance $\times$ Quality

Overall Equipment Efficiency (OEE) $=\frac{B}{A} \times \frac{D}{C} \times \frac{E}{F}$

The OEE indicator signalizes to those in charge of maintenance in which major waste sources they need to focus in order to enhance the equipment performance and make directed improvements (Fuentes, 2006; Bariani and Del'Arco Júnior, 2006).

\begin{tabular}{|c|c|c|}
\hline Indicators & \multicolumn{2}{|c|}{ Total operating time } \\
\hline \multirow{2}{*}{ Availability } & A. Net Operating Time & $\begin{array}{c}\text { Non-programmed } \\
\text { Production }\end{array}$ \\
\cline { 2 - 3 } & B. Scheduled Production Time & $\begin{array}{c}\text { Failed } \\
\text { Set-up }\end{array}$ \\
\hline \multirow{2}{*}{ Performance } & C. Intended Output & \\
\cline { 2 - 3 } & D. Real Output & $\begin{array}{c}\text { Short } \\
\text { Downtimes }\end{array}$ \\
\hline \multirow{2}{*}{ Quality } & F. Good Output & \\
\cline { 2 - 3 } & E. Real Output & $\begin{array}{c}\text { Reject } \\
\text { Rework }\end{array}$ \\
\end{tabular}

Figure 1. Main wastes and impact on the real operating time (Source: adapted from Setec Consulting Group, 2008).

Table 1. Indices and main downtimes (Source: adapted from Setec Consulting Group, 2008).

\begin{tabular}{|c|l|}
\hline Indicators & \multicolumn{1}{|c|}{ Main wastes } \\
\hline \multirow{2}{*}{ Availability } & $\begin{array}{l}\text { Identifyable downtimes } \\
\text { Equipment failure and wear of tools } \\
\text { Wastes due to adjustments and setups }\end{array}$ \\
\hline Performance & $\begin{array}{l}\text { Wastes due to lowered speed } \\
\text { Downtimes and short downtimes }\end{array}$ \\
\hline Quality & $\begin{array}{l}\text { Quality loss } \\
\text { Wastes of the process }\end{array}$ \\
\hline
\end{tabular}


According to Bariani and Del'Arco Júnior (2006, p. 72):

The OEE measures the equipment ability in consistently producing pieces that meet the quality standards within a designated time cycle and with no downtimes, the availability, the performance and the quality rate of a machine. It provides a method to analyze wastes and measure the results of the actions taken.

In the researched literature, Hansen (2006) refers to OEE higher than $85 \%$ for batch processes and higher than $90 \%$ for streaming industries.

De Ron and Rooda (2006) point out some important considerations about OEE. According to their researches, the indicator does not take into account all of the factors that reduce the capacity of use, as for instance: planned downtimes, lack of raw material to produce and lack of manpower.

Hansen (2006), De Ron and Rooda (2006) and Sharma et al. (2012) corroborate that the OEE accuracy is determined by the quality of the collected data. The authors also highlight that the OEE undergoes the impact of factors beyond the equipment itself (the operator, the product formulation, raw materials availability, programming requests), showing itself to be useful in production environments where the equipment is used in an integrated way.

\section{Analysis and Result Discussion}

According to the systematic proposed in this study, the data collected was analyzed in parts. Firstly, the line downtimes were stratified per day and after the calculation of OEE indicator - when it was possible - each index (Availability, Performance and Quality) was compared with an indicator that was already in use in the plant.

\section{Line Downtimes}

Every operator had a list with the classification of the main problems and their corresponding code. After tabulating the production line downtime during the studied period, 13 different problems related to different equipments or reasons pointed out in Table 02 were written up:

Figure 2 shows the main downtimes pointed out along the production shift and it was observed through it that the longest line downtimes were caused by problems related to the inkjet printer (code 6004) and the filler (code 6003), respectively.

Although they had a spare inkjet printer, the company spent 245 and 273 minutes to repair the equipment between the studied days 04 and 05 . The mechanical downtimes in the equipment - fundamental to print validity, time and lot on the cover of PET bottle caps- consumed on these two days about $6 / 5$ of a production shift.

The code 6003 , referring to downtimes caused by problems with the filler, consumed 473 minutes, having occurred 44 times during the period assessed in this work (Figure 3). 
Table 2. Line downtime codes.

\begin{tabular}{|c|c|c|}
\hline No. & Code & Motive of the line downtime \\
\hline 1 & 1408 & Adjustment in the equipment due to kit replacement \\
\hline 2 & 2402 & Adjustment in the temperature of the pasting machine \\
\hline 3 & 3103 & Electrical problem at heating the oven \\
\hline 4 & 3109 & Electrical problem with the fans of the oven \\
\hline 5 & 5007 & Lack of steam from the boiler \\
\hline 6 & 5009 & Problem in the depalettizing \\
\hline 7 & 6001 & Problem in the syrup equipment \\
\hline 8 & 6002 & Problem in the filler \\
\hline 9 & 6003 & Problem in the inkjet printer \\
\hline 10 & 6004 & Problem in the packer \\
\hline 11 & 6006 & Delay of breakfast and return from the lecture \\
\hline 12 & 7001 & Meeting \\
\hline 13 & 7004 &
\end{tabular}

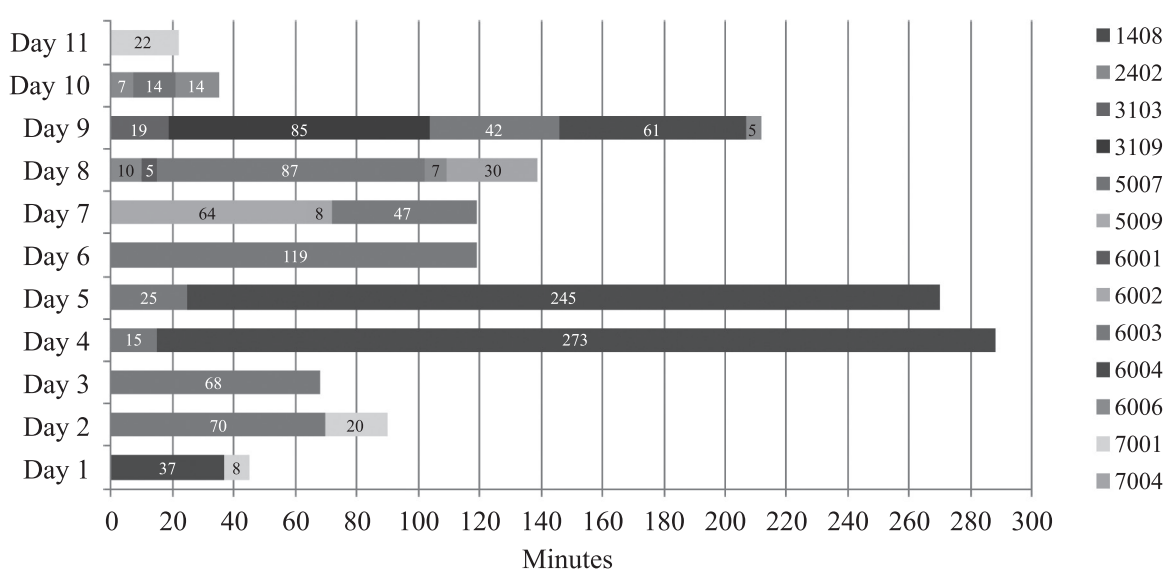

Figure 2. Production line downtimes segmented by codes and by day.

The downtimes were segmented by time interval and the major occurrences of line downtimes consumed between 3 and 15 minutes of production, in equivalent proportions, summing 287 minutes (61\% of the whole time) and characterizing the effectuation of short mechanical interventions in the filler for small adjustments (Figure 3).

Many of the line downtimes related to the filler were recorded by the peripheral operators (labeler and packer), having been recorded by the code 6003 , more generic. Such a fact may be due to the following factors:

a) The filler operator intervenes in the equipment maintenance for small adjustments, becoming unable to write up the downtime length; 
b) The filler operator does not hold so short downtimes as significant, and therefore does not make the record;

c) Failure in the operator's training.

\section{OEE - Overall Equipment Efficiency}

The main indicator to measure the overall equipment efficiency (OEE) is a product of the multiplication of the indices Availability, Performance and Quality (Figure 4).

The indicator goal was stipulated based on the benchmark of the System Operations area to which the company belongs. Between the days studied figures for the OEE indicator were found below the established goal $(60 \%)$. The days 04 and 05 show the smallest figures of the OEE, 8 and $11 \%$, respectively. The low index was the result of the long downtimes due to the defect of the line bottle inkjet printer, making the planned programming unable to be achieved (see Figure 2).

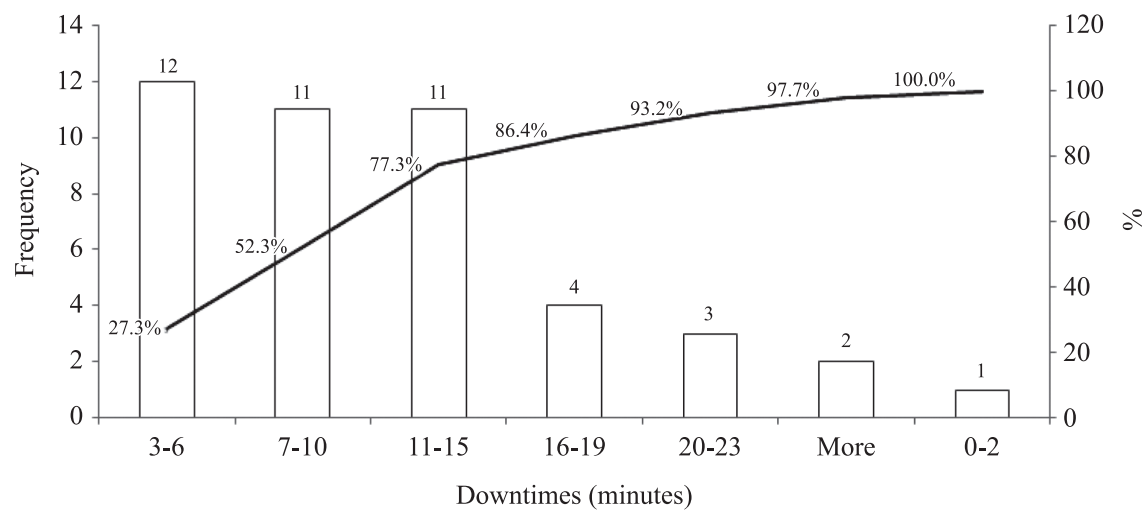

Figure 3. Production line downtime intervals due to a problem with the filler.
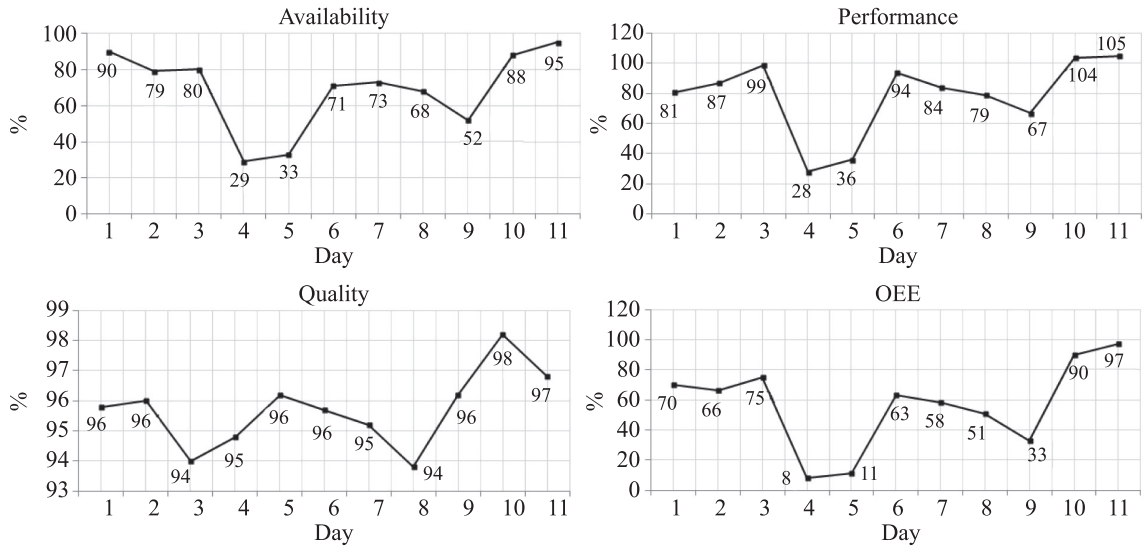

Figure 4. Indices composing the OEE and the OEE indicator for the studied period. 
On day 09 , the third figure below the expected (33\%) was a result of successive electrical problems in the packing, inkjet printer and filler, respectively, compromising the final index.

\section{Comparison between the Current Indices of Development and the Indices of the Proposed Method}

The performance indicator used by the company - \% Attendance to PPC - is similar to the OEE Performance indicator except that the last one does not take into account the extra hours worked to manufacture or rework the accomplished product.

This discount equalized in the OEE Performance indicator also helps in exposing the so called "hidden factory" interference in the process. Stamatis (2004, p. 12) defines hidden factory as:

[...] the hidden cost of a process, due to unaccounted and unrelated costs associated with standard process. Examples are inspection, delays, rework and extra processing. The hidden factory deals with throughput in the process and tries to calculate the probability of an item passing through the process the first time without any defect. Anything else is a loss, and therefore should be counted as the hidden factory.

Whereas the amount of product manufactured through the use of extra hours is shown as gain by the indicator \% Attendance to PPC.

Figure 5 evidences the biasing of the \% Attendance to PPC indicator due to the use of extra hours to compensate the production not performed because of downtimes and equipment failure, or general delays.

It is also possible to notice by Figure 5 that the \% Attendance to PPC indicator always presents values higher than or the same as the OEE Performance indicator.

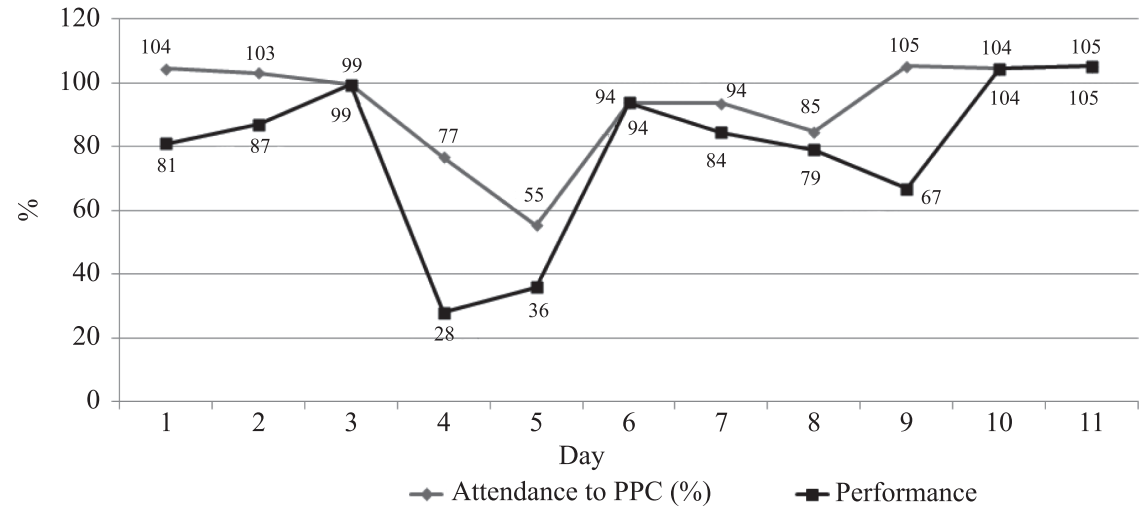

Figure 5. Comparison between \% meeting the PPC indicator and the OEE performance indicator. 
Table 3. Index of return of after filling PET bottles.

\begin{tabular}{|c|c|}
\hline Observations & \% PET bottles returned \\
\hline Day 01 & 3.3 \\
\hline Day 02 & 2.8 \\
\hline Day 03 & 4.9 \\
\hline Day 04 & 4.8 \\
\hline Day 05 & 3.5 \\
\hline Day 06 & 3.3 \\
\hline Day 07 & 4.3 \\
\hline Day 08 & 4.9 \\
\hline Day 09 & 3.5 \\
\hline Day 10 & 1.6 \\
\hline Day 11 & 2.6 \\
\hline Average & $\mathbf{3 . 6}$ \\
\hline
\end{tabular}

It is pointed out that this study was performed based on the program informed by the Production Planning sector. So, there is a gap for a further assessment of the product cycle times, for values above $100 \%$ that were found without modifications in the filler speed or in the other equipments during the study period.

As for the Quality indicator or FTT (First Time Through) there is none similar established by the company. The waste index was used as a form of monitoring the discarded PET bottles. According to the history, the waste of these bottles was around $3 \%$.

The initial focus of this study was based on the significance of the reutilization of after-filling bottles. According to Table 3, an average of $3.6 \%$ of the bottles in good conditions of use was reutilized for new bottling processes.

Although the practice of PET bottle rework is no more performed by the company, it is deemed that the monitoring of the percentage of return of PET bottles could be a process indicator to check if the actions taken to improve the OEE indicator impact in the reduction of this index.

Even though the process shows expressive figures for the Quality indicator, between 93 and 98\% (see Figure 4), there are opportunities of improvement to enhance this indicator. In a future monitoring the stratification of the quality problems shown by the non-compliant packages through Pareto's chart is appropriate in order to find out the possible causes for the failures.

\section{Conclusions and Recommendations for Future Studies}

According to the results that were found during the period of this case study, all the presumptions were confirmed and the currently used indicators do not guide to take correct decisions, showing that the management does not act proactively to reduce the wastes. 
This work also proposes the application of a methodology that would be adequate for analyzing and stratifying the production line downtimes in order to enhance the operational efficiency in beverage PET bottling and correlate the OEE indicator with the other operational indicators that already exist in the plant.

The indicators already deployed such as \% Attendance to PPC show a strong correlation with the OEE indicator, clearly signalizing the use of extra hours to rework the packages or increase the production due to low efficiency of the shift. This fact shows effectively that the selected indicator complies with its role of pointing out failures in the process or the accomplished product quality in order to enhance the operational efficiency.

Although the practice is no more used by the organization, rework has a direct effect on the company productivity, generating an average return rate of $3.6 \%$ over the total bottles used during the analyzed period.

As suggestions for further researches, the performance of benchmarking in other beverage companies in the same industrial segment is recommend in order to define optimal production parameters and identify the best practices. Additionally it is suggested: to stratify longer downtimes in order to investigate the cause and avoid or minimize new occurrences, and to monitor periodically the production process, aiming at improving the operational efficiency.

\section{References}

Bariani, L. and Del'Arco Júnior, A.P. (2006) Utilização da tecnologia da informação por grupos integrados de manufatura para o controle de indicadores de produção enxuta. Revista de Ciências Humanas, Vol. 12, No. 1, pp. 67-79, jan./jun.

De Ron, A.J. and Rooda, J.E. (2006) OEE and equipment effectiveness: an evaluation. International Journal of Production Research, Vol. 44, No. 23, pp. 4987-5003. http://dx.doi. org/10.1080/00207540600573402

Falcão, A.S.G. (2001) Diagnóstico de perdas e aplicação de ferramentas para o controle da qualidade e melhoria do processo de produção de uma etapa construtiva de edificações habitacionais. Dissertação. Universidade Federal do Rio Grande do Sul, Porto Alegre, Brasil.

Fernandes, P.M.P. and Ramos, A.W. (2006) Considerações sobre a integração do Lean Thinking com o Seis Sigma, in: XXVI Encontro Nacional de Engenharia de Produção, ABEPRO, Fortaleza.

Fuentes, F.F.E. (2006) Metodologia para inovação da gestão de manutenção industrial. Tese. Universidade Federal de Santa Catarina, Florianópolis, Brasil.

Giannini, R. (2007) Aplicação de ferramentas do pensamento enxuto na redução de perdas em operações de serviços. Dissertação. Universidade de São Paulo, São Paulo, Brasil.

Gomes, N.D. (2002) Manutenção Produtiva Total: proposta de um instrumento de avaliação objetivando verificar o grau de adequação aos pilares da TPM. Dissertação. Universidade Federal Fluminense, Niterói, Brasil.

Hansen, R.C. (2006) Eficiência global dos equipamentos: uma poderosa ferramenta de produção/manutenção para o aumento dos lucros. Porto Alegre: Bookman.

Kmita, S.F.; Portich, P. and Guimarães, L.B.M. (2003) Custos ergonômicos +7 perdas: 8 perdas no sistema de produção, in: XXIII Encontro Nacional de Engenharia de Produção, ABEPRO, Ouro Preto. 
Lacerda, D.P.; Silva, E.R.P.; Navarro, L.L.; Oliveira, N.N.P. and Caulliraux, H.M. (2007) Algumas caracterizações dos métodos científicos em engenharia de produção: uma análise de periódicos nacionais e internacionais, in: XXVII Encontro Nacional de Engenharia de Produção, ABEPRO, Foz do Iguaçu.

Maran, M.; Manikandan, G. and Thiagarajan, K. (2012) Overall Equipment Effectiveness Measurement by Weighted Approach Method, in: International MultiConference of Engineers and Computer Scientists, IAENG, Hong Kong.

Masud, A.K.M.; Al-Khaled, A.; Jannat, A.K.M. S.; Khan, S.A. and Islam, K.J. (2007) Total Productive Maintenance in RMG sector A case: Burlingtons Limited, Bangladesh. Journal of Mechanical Engineering, Bangladesh, Vol. ME37, pp. 62-65. http://dx.doi.org/10.3329/jme. v37i0.827

Moellmann, A.H.; Albuquerque, J.L.C. and Marins, F.A.S. (2006) Aplicação da teoria das restrições e do indicador de eficiência global do equipamento para melhoria de produtividade em uma linha de fabricação. Revista Gestão Industrial, Vol. 2, No. 1, pp. 89-105. http://dx.doi. org/10.3895/S1808-04482006000100009

Moraes, L.H. and Santoro, M.C. (2006) Medida de eficiência em linhas de produção, in: XXVI Encontro Nacional de Engenharia de Produção, ABEPRO, Fortaleza.

Muchiri, P. and Pintelon, L. (2008) Performance measurement using overall equipment effectiveness (OEE): literature review and practical application discussion. International Journal of Production Research, Vol. 46, No. 13, pp. 3517-3535. http://dx.doi. org/10.1080/00207540601142645

Passos, A.; Antunes Júnior, J.A. and Klippel, M. (2004) Considerações críticas sobre a eficiência nos sistemas produtivos industriais - uma abordagem a partir do Sistema Toyota de Produção e da Teoria das Restrições, in: Encontro Nacional de Engenharia de Produção, ABEPRO, Florianópolis.

Rodrigues, M.G.V.; Madeira, J.F.C.; Santos, L.E.P. and Domingues, C.A. (2005) Metodologia da pesquisa: elaboração de projetos, trabalhos acadêmicos e dissertações em ciências militares. 3. ed. Rio de Janeiro: EsAO/RJ.

Setec Consulting Group (2008). Apostila Setec Consulting Group Treinamento Seis Sigma Green Belt - Melhoria DMAIC. revision 5.

Sharma, A.K.; Shudhanshu and Bhardwaj, A. (2012) Manufacturing performance and evolution of TPM. International Journal of Engineering Science and Technology, Vol. 4, No. 3, pp. 854-866.

Souza, F.J. (2004) Melhoria do pilar "Manutenção Planejada" da TPM através da utilização do RCM para nortear as estratégias de manutenção. Dissertação. Universidade Federal do Rio Grande do Sul, Porto Alegre, Brasil.

Stamatis, D.H. (2004) Six Sigma fundamentals: a complete guide to the system, methods and tools. New York: Productivity Press.

\section{Biography}

Fabiana Pereira Castro holds the degrees of Food Engineer from the Rural Federal University of Rio de Janeiro (UFRRJ) and Master of Business Administration in Total Quality Management from the Fluminense Federal University (UFF). She is Production Engineering student in Production Engineering Department at the Federal Centre for Technological Education of Rio de Janeiro (CEFET/RJ). She has experience in Integrated Management System and her research interest includes design, control of production and manufacturing systems, Lean Manufacturing and Total Productive Maintenance (TPM).

Contact: f_pcastro@yahoo.com.br 
Fernando Oliveira de Araujo is Professor and Researcher of Production Engineering Department at the Federal Center for Technological Education of Rio de Janeiro (CEFET/RJ). He holds the degrees of Production Engineer and M.Sc. in Management Systems from the Fluminense Federal University (UFF) and Ph.D. in Production Engineering from the Catholic University of Rio de Janeiro (PUC-Rio). His research interest includes operations and production management, design and control of production and manufacturing systems, industrial organization, business strategies, innovation and sustainability.

Contact: faraujo@sustentabile.com.br

\section{Article Info:}

Received: September, 2011

Accepted: August, 2012 